
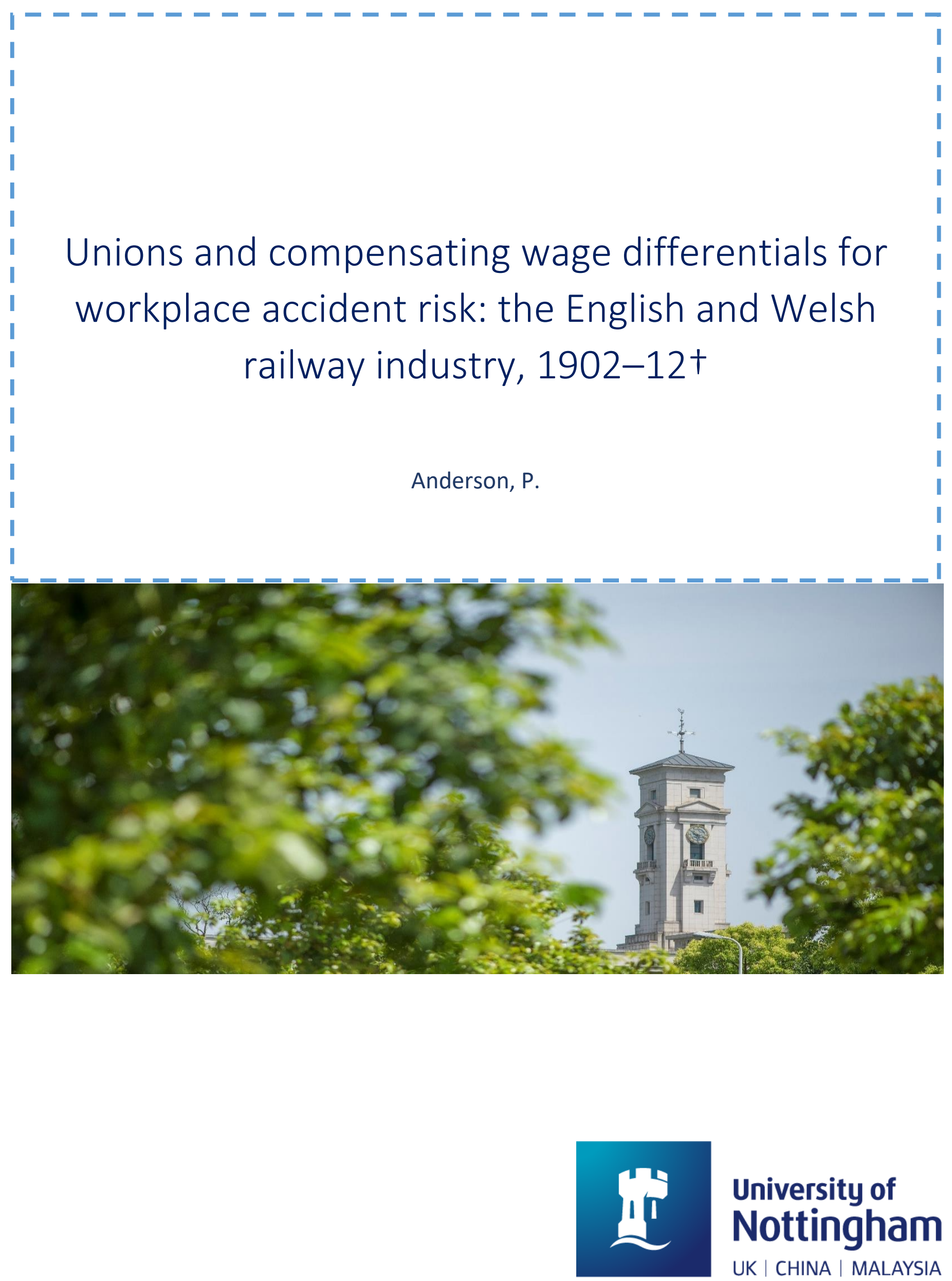
University of Nottingham Ningbo China, 199 Taikang East Road, Ningbo, 315100, Zhejiang, China.

First published 2021

This work is made available under the terms of the Creative Commons Attribution 4.0 International License:

http://creativecommons.org/licenses/by/4.0

The work is licenced to the University of Nottingham Ningbo China under the Global University Publication Licence:

https://www.nottingham.edu.cn/en/library/documents/researchsupport/global-university-publications-licence-2.0.pdf 


\title{
Unions and compensating wage differentials for workplace accident risk: the English and Welsh railway industry, $1902-12^{\dagger}$
}

\author{
By PETER ANDERSON
}

\begin{abstract}
The effect of unions on workers' wage premiums for accepting on-the-job accident risk is a prominent subset of compensating differentials research. This article contributes to the literature by using a newly-constructed balanced panel of railwaymen working in the traffic departments of three prominent Edwardian railway companies with operations in England and Wales. It avoids previous issues of endogeneity by controlling for a number of variables correlated with the risk rates, notably individual fixed effects. The results show that the largest railway union of the time, the Amalgamated Society of Railway Servants, was able to transform growing union density into power that increased wage premiums for fatal accident risk, although railwaymen's wages did not compensate them for non-fatal accident risk. This article also considers how this relationship differed by varying levels of company-specific human capital as measured by tenure. It finds a non-linear relationship for both risk rates across the tenure cohorts.
\end{abstract}

he theory of compensating differentials asserts that wages will adjust to equalize differences between jobs. ${ }^{1}$ This insight from Adam Smith has primarily spawned papers that have found evidence of companies paying workers higher wages or 'bribes' to accept the 'bad' that is on-the-job fatal accident risk because it is safe to assume that workers universally dislike the risk of being killed at work. ${ }^{2}$ Some researchers have tested whether unions or union membership affect the premium employees receive for working in unsafe conditions. Fairris hypothesized that unions may negatively affect compensating differentials if they implement automatic pay scales or eliminate perceived arbitrary differences in pay that actually reflect differences in risk. He called this 'wage levelling', ${ }^{3}$ Other benefits gained from collective bargaining, such as a reduction in the length of the work

\footnotetext{
* Author's Affiliation: University of Nottingham Ningbo China.

$\dagger$ This article is a revised version of chapter 6 of my D.Phil. thesis and I would like to thank my supervisor, Jane Humphries, in addition to my examiners, Peter Scott and Knick Harley. I would also like to thank Price V.Fishback who first suggested I investigate compensating differentials in the Edwardian railway industry and later provided helpful comments on an earlier draft of this article. The article has also benefited from helpful suggestions by Paolo Bianchi and attendants at the University of Nottingham Ningbo China's School of Economics Academic Seminar. I would also like to thank Qian Keyang, Xu Chaoxu, and Hanyi Li for helpful data entry. The usual disclaimers apply.

${ }^{1}$ Smith, Wealth of nations, pp. 201-2.

${ }^{2}$ Viscusi, 'Value of risks', pp. 1926-7.

${ }^{3}$ Fairris, 'Compensating wage differentials', pp. 358-60.
} 
week or higher overtime earnings, may also compensate workers for higher risk. Alternatively, unions may provide workers with better information about the risk they face or counteract large employers' ability to push down wages, both of which should lead to higher compensating differentials. ${ }^{4}$ The way unions influence compensating differentials for accident risk ultimately depends on the ends the unions pursue. ${ }^{5}$

Empirical studies have not reached a consensus. In modern labour markets, Viscusi and Aldy's survey reports that 'Most studies of the U.S. labor market find that union affiliation is positively correlated with a greater wage-risk trade-off while the international evidence is much more mixed'. ${ }^{6}$ The same is true of historical research on this topic. Fishback and Kantor's study of American workers during the Progressive Era report that union members received higher wage premiums for accident risk in one state but not in two others. ${ }^{7}$ Kim and Fishback's historical study of American railroads, to which this article owes a debt, finds that compensating differentials for accident risk declined at a time of increasing union importance. ${ }^{8}$

This uncertainty is compounded by the fact that the majority of papers studying the impact of unions on compensating differentials are affected by omitted-variable bias, which at the very least calls into question the reported magnitude of the risk rates' coefficients. Viscusi and Aldy's survey reveals that only one of the 14 papers on this topic in non-US labour markets, Kim and Fishback's 1999 paper on South Korea, controls for fatal accident risk, non-fatal accident risk, and the effect of workers' compensation laws on these accident differentials. ${ }^{9}$ All of these variables are highly correlated and not including them leads to issues of endogeneity. Kim and Fishback's paper, however, is not directly comparable to the other studies because of its unique use of a panel of industries instead of individual workers. ${ }^{10}$ Related to this, the paucity of individual-level panel data in compensating differentials estimations ${ }^{11}$ means most studies have not controlled for the time-invariant aspects of an individual that are correlated to the accident risk of the job he or she chooses. Workers skilled at avoiding on-the-job danger may sort into higher-paying, riskier jobs ${ }^{12}$ while higher-quality workers that deem safety a normal good will sort into higher-paying, safer jobs. ${ }^{13}$ Failure to control for the former will lead to an overestimate of the wage premium for accepting on-the-job risk, while failure to control for the latter can lead to a negative correlation between risk and remuneration.

\footnotetext{
${ }^{4}$ Viscusi and Aldy, 'Value of a statistical life', pp. 43-4.

${ }^{5}$ Crouch, Trade unions, p. 139.

${ }^{6}$ Viscusi and Aldy, 'Value of a statistical life', p. 43.

${ }^{7}$ Fishback and Kantor, "'Square deal", pp. 843-4.

${ }^{8} \mathrm{Kim}$ and Fishback, 'American railroading', pp. 812-13.

${ }^{9}$ Viscusi and Aldy, 'Value of a statistical life', pp. 45-9. US labour market studies fare little better, with only three of 16 papers controlling for all of these variables. A closer look, however, shows that Dorman and Hagstrom, 'Wage compensation', pp. 127-8n., never control for fatal and non-fatal risk in the same regression. Dorsey and Walzer, 'Workers' compensation', pp. 645-6, use industry-level risk rates rather than occupational risk rates, which they try to remedy by excluding white-collar workers who have a much lower risk of injury in the same industry. The third, to which I did not have access, is a chapter authored by Dorsey in which he uses industry averages as his unit of observation. See Viscusi and Aldy, 'Value of a statistical life', p. 22.

${ }^{10} \mathrm{Kim}$ and Fishback, 'Impact', pp. 236-7.

${ }^{11}$ Viscusi and Aldy, 'Value of a statistical life', p. 16.

12 Kniesner, Viscusi, Woock, and Ziliak, 'Evidence from panel data', p. 74.

${ }^{13}$ Lavetti, 'Estimation', p. 165.
} 
To my knowledge, this article is the first to apply individual-level panel data to the question of how unions impact on compensating differentials. It uses a newly-compiled balanced panel of 838 railwaymen spanning the years 1902-12 to determine whether the largest railway union in the UK, the Amalgamated Society of Railway Servants (ASRS), was able to translate growing railway union density and changes in wage-determining institutions into power that affected Edwardian railwaymen's compensating differentials for accident risk. ${ }^{14}$ This article's estimates avoid endogeneity by controlling for railwaymen's time-invariant determinants of the jobs they chose, fatal accident risk, non-fatal accident risk, and change in the Workmen's Compensation Act during this period, while analysis of the same industry prevents conflation of the risk premiums with industry-specific premiums. ${ }^{15}$ The results show that the ASRS was able to transform growing union density into power that increased the wage premiums that railway companies paid their men to accept on-the-job fatal accident risk, although their wages did not compensate them for greater non-fatal accident risk. Finally, the article considers how these accident-risk premiums varied by differing levels of company-specific human capital as measured by tenure, finding a non-linear relationship for both risk rates across the tenure cohorts.

The rest of the article is organized as follows. Section I looks at the wage-setting process in the UK railway industry and how railway unions played a role in changing this. Section II explains the dataset and the risk variables used. Section III describes the fixed effects model used to estimate railwaymen's compensating differentials for fatal and non-fatal accident risk. Section IV assesses the regressions' outcomes, and section $\mathrm{V}$ provides concluding remarks.

The Edwardian UK railway industry was a dangerous place to work by both contemporary and modern standards. The fatal accident risk rates for goods guards and shunters, the two most dangerous railway grades, because they both performed shunting duties, ${ }^{16}$ were more than two times higher than those of miners, quarrymen, or textile workers. ${ }^{17}$ In the six years preceding the First World War, the railway industry's fatal compensation cases comprised an average of 11.3 per cent of the total fatal cases from the seven industries originally required to compensate employees and their dependents under the Workmen's Compensation Act. ${ }^{18}$ From 1900 to 1913 , an average of 470.7 and 452.3 railwaymen died per year in workplace

\footnotetext{
14 The term 'power' is used throughout this article in the way requoted by Levesque and Murray, 'Understanding union power', p. 335. It is 'the "power to", which is union "agents' abilities to bring about significant effects, specifically by furthering their own interests and/or affecting the interests of others, whether positively or negatively" (Lukes, Power, p.65)'.

${ }^{15}$ Dorman and Hagstrom, 'Wage compensation'; Dillingham, 'Influence'; Leigh, 'Compensating wages'.

16 For further details of each grade's duties, see 'Dictionary of occupational terms', http://doot.spub.co.uk/listing.php (accessed on 17 March 2021).

17 TNA, Railwaymen's charter, ZLIB 29/630, p. 9.

18 Statistics of Compensation (P.P. Annual Returns). The Great Eastern Railway (GER) contracted out their compensation and these returns do not include their fatalities. Only the 1908-13 returns include deaths caused by industrial diseases. The seven original industries-shipping, factories, docks, mines, quarries, construction, and railways - had an annual average of 3,615 fatal accidents compensated under this Act in these six years.
} 
accidents in the UK and Great Britain, respectively, ${ }^{19}$ while the whole of Great Britain had 141 total workplace deaths in 2017/18. ${ }^{20}$

If Edwardian railwaymen earned compensating differentials, it is because their companies' internal wage-determining institutions reflected levels of workplace accident risk. Company-specific internal labour markets (ILMs) determined the grades at which men entered railway service, job ladders, promotion rates, and wages. $^{21}$ They also exhibited some flexibility, as companies could adjust wages to reflect local variations in levels of risk for specific groups of employees. When railwaymen had a complaint, a deputation of men would communicate it to local company officials in a meeting or by a signed petition that enumerated the men's desired changes. The local officials would then forward these complaints to senior officials with the power to rectify the grievances. ${ }^{22}$ Changes in wages could also be particular, as railway companies sometimes made changes in pay scales for specific grades at specific stations. ${ }^{23}$

Prior to 1907, railway unions had little influence on the wage-setting process and only the North Eastern Railway (NER) formally recognized the oldest and largest railway union, the ASRS. Founded in 1871, the ASRS represented railwaymen 'connected with the manipulation of traffic', but excluded grades they considered distinct trades, such as the coachbuilders employed in the works at Swindon and Crewe, in addition to salaried grades such as station masters and clerks. ${ }^{24}$ The three grades in this study's panel-goods guards, passenger guards, and signalmencould all join the ASRS. Table 1 shows the number of ASRS members for selected grades in 1904 and 1911 along with the percentage of that grade belonging to the ASRS and its membership as a percentage of total ASRS membership. ${ }^{25}$

In addition to the ASRS, three other main railway unions sought to represent non-salaried railwaymen. The Associated Society of Locomotive Engineers and Firemen (ASLEF) only catered to grades in locomotive departments: the drivers, firemen, and engine cleaners. As shown in table 1, some men in these grades also joined the ASRS, which had more engine drivers and firemen as members in 1904 than the total ASLEF membership. ASLEF membership surpassed the ASRS's numbers in these two grades in 1911, but only by slightly more than 1,600 men. The General Railway Workers' Union (GRWU) represented railwaymen who could not join the ASRS. This included men working in railway shops, permanent-way men, and railwaymen employed in goods departments. The United Pointsmen's and Signalmen's Society (UPSS) only allowed signalmen to join its ranks, ${ }^{26}$ although more signalmen joined the ASRS.

${ }^{19}$ Railway Accidents (P.P. Annual Returns). This includes the servants of contractors killed while working on the railways.

${ }^{20}$ Health and Safety Executive, 'RIDFATAL', tab. 1.

${ }^{21}$ Howlett, 'Evidence', and idem, 'Internal labour dynamics', provide details of the GER's traffic department's ILM. Savage, 'Discipline', covers the GWR locomotive department's ILM. Anderson, "Tall and lithe"”, gives a broader overview of ILM workings.

${ }^{22}$ R.C. on the Railway Conciliation Scheme of 1907. Minutes of Evidence (P.P. 1912/13, XLV), Q.3,922, Q.7,408,

23 TNA, Register of London and North Western Railway (LNWR) salaried and waged staff, RAIL 410/1804. This is a typed circular attached to fo. 321 and explains the change in the pay scale that applied to brakesmen working at Bescot.

${ }^{24}$ Clerks could join the Railway Clerks' Association.

${ }^{25}$ Gupta, 'Railway trade unionism', p. 126n. The ASRS only provided membership by grade in 1875,1898 , and 1904

${ }^{26}$ R.C. on the Railway Conciliation Scheme of 1907. Minutes of Evidence (P.P. 1912/13, XLV), Q.2,024. 
Table 1. ASRS membership by selected grade

\begin{tabular}{llllllll}
\hline & \multicolumn{3}{c}{1904} & & \multicolumn{3}{c}{1911} \\
\cline { 2 - 3 } & $\begin{array}{l}\text { Total } \\
\text { members }\end{array}$ & $\begin{array}{l}\text { Grade } \\
(\%)\end{array}$ & $\begin{array}{l}\text { ASRS } \\
(\%)\end{array}$ & & $\begin{array}{l}\text { Total } \\
\text { members }\end{array}$ & $\begin{array}{l}\text { Grade } \\
(\%)\end{array}$ & $\begin{array}{l}\text { ASRS } \\
(\%)\end{array}$ \\
\hline Goods guards & 8,454 & 55.9 & 15.8 & 9,738 & 63.5 & 12.9 \\
Passenger guards & 2,137 & 28.1 & 4.0 & & & \\
Signalmen & 6,462 & 23.1 & 12.1 & & 10,651 & 37.1 & 14.2 \\
Engine drivers & 8,740 & 34.9 & 16.3 & & 10,233 & 37.4 & 13.6 \\
Firemen & 6,694 & 28.8 & 12.5 & & 11,554 & 45.5 & 15.3 \\
Shunters & 5,585 & 47.1 & 10.4 & & 9,851 & 74.2 & 13.1 \\
\hline
\end{tabular}

Notes: ASRS: Amalgamated Society of Railway Servants. The 1904 union data by grade pertain to Sept. 1904. Gupta, 'Railway trade unionism', used 1904 accident returns to calculate the percentage of each grade that was unionized. He also provided the number of members in a grade as a percentage of ASRS membership. Based on these latter figures, the extrapolated ASRS membership ranges from 50,882 to 62,853 members. Friendly Societies (P.P. 1905, LXXV), p. 411, puts total ASRS membership at the end of 1904 at 53,407, which is the number used to calculate 'ASRS (\%)' for 1904. J. H. Thomas testified before the 1911 Royal Commission that his membership data by grade came from the previous week, which would make it the week beginning Monday 21 Aug. 1911. The no. of signalmen is based on membership numbers for that grade at the end of June 1911. The percentages come from employment figures in 1910, while total ASRS membership comes from what was reported for the ASRS at the end of 1910. Thomas cited no membership data for passenger guards.

Sources: 1904 membership: Gupta, 'Railway trade unionism', pp. 151-2; Friendly Societies (P.P. 1905, LXXV), p. 411.1911 membership: R.C. on Conciliation (P.P. 1912-13, XLV), Q.2,024 (non-signalmen grades), Q.6,602 (signalmen). 1910 employment by grade: Railway Accidents (P.P. 1911, LXX), p. 41. 1910 ASRS membership: Friendly Societies (P.P. 1911, LXXVI), p. 740.

Based on table 1's figures, the ASRS had 2.65 times more signalmen as members than the UPSS in 1904, a number that grew to 2.8 times greater by 1911 . In 1913, the ASRS, GRWU, and UPSS amalgamated to form the National Union of Railwaymen (NUR). The ASLEF remained independent and is so to this day.

Figure 1 shows these unions' members as a percentage of non-salaried UK railwaymen for the years 1900-13. Employment totals come from the Board of Trade's (hereafter the Board) annual reports on the wages and hours of labour which reported employment for the 27 largest railway company employers. Employment data from 1911 show that these companies employed about 95 per cent of UK railwaymen. ${ }^{27}$ The Board's figures on total railwaymen were adjusted accordingly and then rounded to the nearest whole number to compute total non-salaried railway employment for a given year. The union density figures are calculated in this way for a few reasons. The first is that salaried railwaymen were ineligible to join any of these four unions. Second, this method demonstrates the changes and growth in total union density within the railway industry. Lastly, the ASRS had more influence among both railwaymen and companies because it had a higher percentage of total railwaymen as members rather than just claiming a high percentage of a few select grades. ${ }^{28}$

The period 1907-12, when ASRS union density never fell below its highest level in the preceding years, saw the advent of institutional changes in the railway industry's wage-setting process. In 1907, the ASRS and ASLEF sent their respective National Programmes to each railway company and requested a meeting to discuss the Programmes' demands for improved wages and working conditions. All of the companies rebuffed the unions' overtures except the NER.

\footnotetext{
${ }^{27}$ Railway Companies (Staff and Wages) (P.P. 1913, LVIII).

${ }^{28}$ Section III discusses of the low percentage of ASLEF, GRWU, and UPSS members elected to 1907 Scheme boards relative to ASRS members.
} 


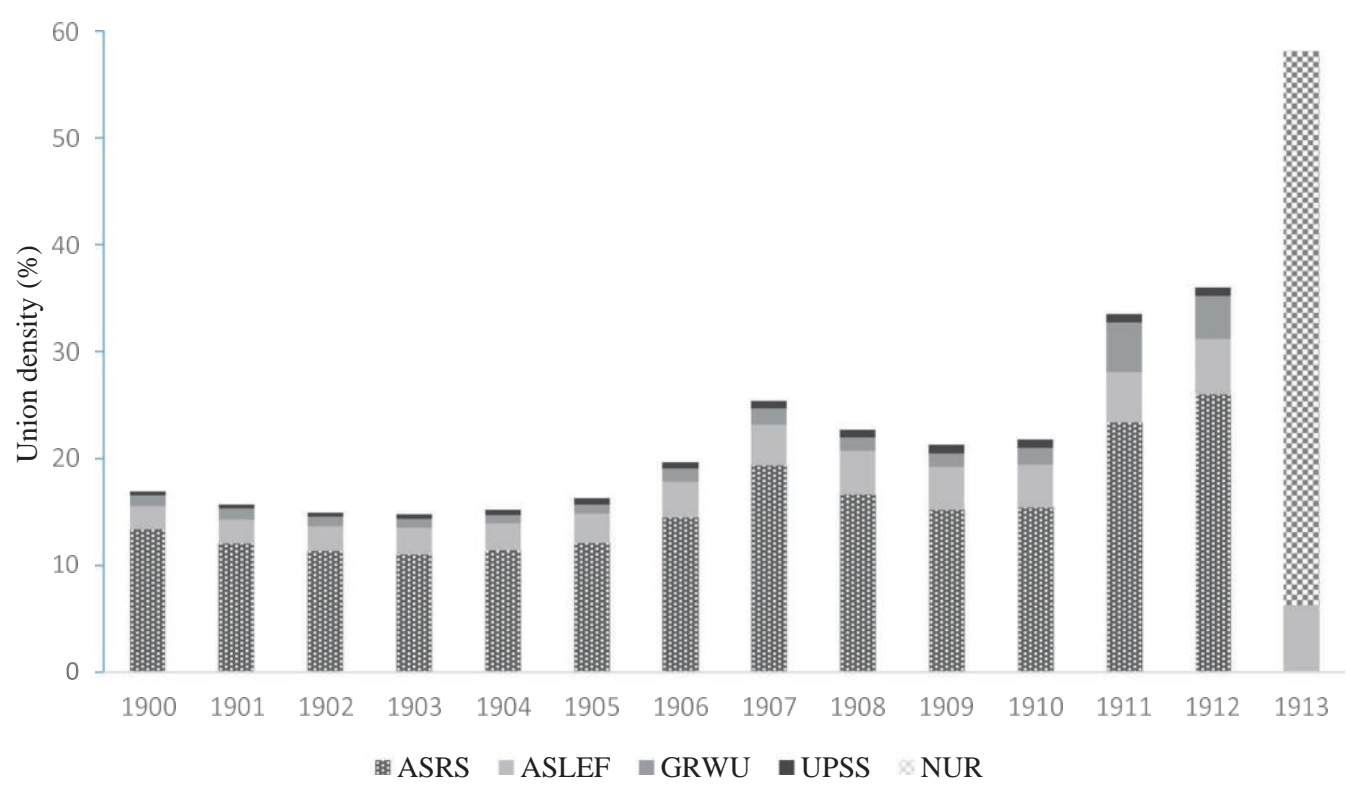

Figure 1. Railwayunion membership as apercentage of UKnon-salaried railwaymen, 1900-13 [Colour figure can be viewed at wileyonlinelibrary.com]

Notes: The same no. of total UK non-salaried railwaymen deflates membership for each union. See section I for a more detailed explanation. ASRS: Amalgamated Society of Railway Servants; ASLEF: Associated Society of Locomotive Engineers and Firemen; GRWU: General Railway Workers' Union; UPSS: United Pointsmen's and Signalmen's Society; NUR: National Union of Railwaymen. The ASRS, GRWU, and UPSS amalgamated in 1913 to form the NUR.

Sources: Union membership: Friendly Societies (P.P. 1903-14, Annual Returns); non-salaried UK railwaymen employment: Wages and Hours of Labour (P.P. 1903-14/16, Annual Returns).

ASRS leadership put strike action before its members for a vote in October 1907 and more than 78 per cent of the returned ballots opted to strike to force the companies to discuss the National Programme with union representatives. ${ }^{29}$ The task of preventing a strike fell upon Lloyd George, then president of the Board, who brokered a compromise between the companies and unions known as the Railway Conciliation and Arbitration Scheme of 1907 (hereafter the 1907 Scheme). ${ }^{30}$

The 1907 Scheme introduced a hierarchical structure of conciliation boards for the negotiation of changes to 'rates of wages and hours of labour'. Railwaymen would first be grouped into sections based on their grade. When a section of railwaymen and their company could not resolve matters through 'the usual channels' the railwaymen's elected representatives met company officials at the Sectional Boards. Unresolved negotiations at this stage proceeded to the Central Boards. If the railwaymen and company representatives still could not reach an agreement, then the matter went before an independent arbitrator whose award was binding. Only at the arbitration stage could union officials not in the employ

\footnotetext{
${ }^{29}$ Howell, Respectable radicals, p. 12.

${ }^{30}$ Of the four major railway unions, only the UPSS representative did not sign the 1907 Scheme. See R.C. on the Railway Conciliation Scheme of 1907. Minutes of Evidence (P.P. 1912/13, XLV), QQ.5,545-9. The NER formed a separate agreement. See ibid., QQ.6,143-4.
} 
of that company represent the men. ${ }^{31}$ Regarding the changes made by the 1907 Scheme to railway company ILMs, the Webbs wrote that 'for the first time the autocracy of the railway management was broken'; 32 while the general manager of the Midland Railway called the companies' assent to arbitration 'revolutionary' because it took away the companies' 'power of deciding' railwaymen's 'rates of pay and ... hours' ${ }^{33}$

The 1907 Scheme was to last seven years and despite initial optimism from all sides $^{34}$ the August 1911 British railway strike made it evident that the scheme had failed to pacify railwaymen. Described as 'One of the outstanding strikes of the period', ${ }^{35}$ the official portion of the railway strike ended on 19 August after Lloyd George, now chancellor of the Exchequer, again negotiated a compromise between the two sides. As part of the agreement, a Royal Commission investigated the workings of the 1907 Scheme and gave its report in October. Railway company and union representatives met for three days in December 1911 before they reached an agreement on the Royal Commission's suggested revisions to the 1907 Scheme. ${ }^{36}$ The resulting 1911 Agreement retained the hierarchical structure of the conciliation boards while making some changes, such as eliminating the Central Boards. It also allowed individuals not working for a company to represent the men, which meant railway union officials could argue the men's case at any point in the negotiations. ${ }^{37}$ The 1911 Agreement enhanced railway union officials' power to affect compensating differentials for accident risk if they chose.

Prior to this, ASRS leadership frequently demanded improvements to railwaymen's safety, hours, and compensation for workplace risks. In 1899, Richard Bell, general secretary of the ASRS, wrote to Lord Salisbury and the Board that 'The continually increasing number of accidents' to railwaymen was 'the subject of much anxiety' to the ASRS. ${ }^{38}$ Bell again invoked concerns about workplace safety in defence of the ASRS's 1907 All-Grades Programme which sought higher wages for all railwaymen and an eight-hour workday in addition to a minimum of nine hours rest between shifts. Bell defended these demands, writing that fatality rates calculated at the grade level showed some grades of railwaymen, such as goods guards, had an annual fatality rate greater than other dangerous occupations like miners or quarrymen. ${ }^{39}$ Bell also argued that long working hours led to workplace fatalities and railway accidents, ${ }^{40}$ an argument he reiterated when representing railwaymen at arbitration hearings under the 1907 Scheme. ${ }^{41}$ Both Bell and his successor, J. E. Williams, criticized the companies for increasing the intensity of

\footnotetext{
${ }^{31}$ Clegg, Fox, and Thompson, History of British trade unions, vol. I, p. 426.

${ }^{32}$ Webb and Webb, History of trade unionism, p. 527.

${ }^{33}$ R.C. on the Railway Conciliation Scheme of 1907. Minutes of Evidence (P.P. 1912/13, XLV), Q.12,912.

${ }^{34}$ R.C. Report (P.P. 1911, XXIX), p. 669; 'Peace convention', Economist, 9 Nov. 1907, p. 1904.

${ }^{35}$ Clegg, History of British trade unions, vol. 2, p. 26.

${ }^{36}$ Strikes and Lock-outs (P.P. 1912-13, XLVII), p. 69.

${ }^{37}$ Howell, Respectable radicals, pp. 224-5. The 1911 Agreement remained in place during the First World War, but its company-specific Boards for negotiation became 'peripheral', with some improvements for railwaymen negotiated at the national level during these years.

${ }^{38}$ R.C. on Accidents (P.P. 1900, XXVII), Q.2,605.

39 TNA, Railwaymen's charter, ZLIB 29/630, p. 9.

${ }^{40}$ Ibid., p. 5.

${ }^{41}$ TNA, GER arbitration, RAIL 1025/11, pp. 829-30; TNA, LNWR arbitration, RAIL 1025/17, pp. 288-9; North British Railway arbitration, RAIL 1025/18, p. 130.
} 
Edwardian railwaymen's work and thereby exposing the men to greater danger without having improved wage growth or reduced the hours worked. ${ }^{42}$

\section{II}

This article uses a panel of 838 railwaymen employed by three of the largest railway companies operating in England and Wales: the Great Central Railway (GCR), Great Western Railway (GWR), and London and South Western Railway (LSWR). All three companies ranked among the 10 largest railway employers, which also made them some of the largest UK employers. ${ }^{43}$ These companies were selected because their staff books show a man's employment history. At a minimum, this included an individual's name, date of birth, date of entry into the company, and changes to his grade, weekly wage, or the station where he worked. This record keeping differed from that of other companies ${ }^{44}$ such as the London and North Western Railway (LWNR), whose staff books tracked changes in specific grades at each station, rather than changes for individual railwaymen.

I first collected the histories of 574 of these railwaymen at the National Archives at Kew. ${ }^{45}$ These men's histories covered the years 1896-1913 because my original research used the Board's triennial employment figures to calculate risk rates. This article uses annual employment data to calculate risk rates, which are available for fewer years. ${ }^{46}$ Working with a shorter period meant that the original panel was biased towards older, longer-tenured railwaymen. Torectify this, these companies' staff books were revisited to add a sample of railwaymen whose inclusion was not strictly determined by having worked in one of these three grades since 1896. This new sample was collected in the same way as the previous sample, first generating a random number between one and 10 for each company. If the number for a company was five, for instance, every fifth page in that company's ledgers was examined, and the histories of railwaymen that served as a goods guard, passenger guard, or signalman from 1902 to 1912 were recorded, which produced the histories of 264 more men. ${ }^{47}$

All of the men in the dataset worked in their company's traffic department. Some men worked in two of these three grades, but none held all three positions during

42 TNA, Railwaymen's charter, ZLIB 29/630, p. 17; 'Railway servants' congress', The Times, 8 Oct. 1907, p. 7; Railway Agreements (P.P. 1911, XXIX), QQ.11,017-20.

${ }^{43}$ Wardley, 'Emergence', p. 102. Including salaried railwaymen, the GWR employed just over 70,000 men, the GCR 25,469, and the LSWR 24,898.

44 The GER also recorded their employees' work histories. Peter Howlett gave me access to his panel of GER railwaymen. I did not use it in this study because it consists of relatively old and long-tenured men by the end of 1912. The GER staff books are not available online, which prevented me from adding a younger cohort of GER railwaymen that would have made Howlett's panel more representative. See Howlett, 'Internal labour dynamics', pp. $402-4$.

45 The full dataset contains 182 men from the GCR, 605 from the GWR, and 51 from the LSWR. It does not include women because most jobs in the Edwardian railway industry were held by men. Furthermore, the ASRS did not admit women members and its successor, the NUR, only began accepting women during the First World War. I collected the staff books from TNA, but they are no longer available. They can now be found online at https://www.ancestry.co.uk/search/collections/1728/. GCR: Manchester, Sheffield and Lincolnshire/Piece 235, 237, 241, 243; GWR: Great Western/Uniformed Staff/No. 1 A-W-Z; LSWR: London and South Western/18651925 Wages Staff.

${ }_{46}$ The employment numbers used to calculate the risk rates are discussed later in this section.

${ }^{47}$ This is not to imply that I only added men who began work in these grades in 1902 . 
their career. These three grades comprised 24.5 per cent of total employment and 28.8 per cent of all wages paid in English and Welsh traffic departments in $1913 .{ }^{48}$ They were also vital to a company's operations. During the August 1911 strike, a memo to the government stated that it was imperative to know the percentage of drivers, goods and mineral guards, and signalmen that had gone on strike'. ${ }^{49}$ In terms of their career paths, the Board reported a 'normal system of promotion' by which companies advanced shunters to goods guards, and porters advanced to either signalmen or passenger guards. The panel is then not representative of locomotive departments which had separate pay scales and promotional ladders. ${ }^{50}$ It is also not representative of the entry-level grades, shunters and porters, who had lower company-specific human capital than the men in the dataset and were more likely to quit working for a company because of it. Consequently, market-wide competitive pressures would have played a larger role in determining any compensating differentials received by these entry-level grades.

The panel is also heavily weighted towards GCR and GWR railwaymen and does not contain LSWR passenger guards because their staff books did not specify whether a guard was a passenger guard, although they listed some men as goods guards. Nevertheless, the panel is representative of a wider group of guards and signalmen. Age and wages are the two variables available to compare the dataset against known characteristics of railwaymen in these grades. The ages of the men in the dataset fall within the age range of the majority of men working in these grades in 1911. In this year, guards in the dataset had a median age of 46 years, with a range of 33 to 65. The 1911 census for England and Wales reports that guards aged $\geq 25$ years made up more than 95 per cent of adult guards and those $\geq 35$ years accounted for 69.7 per cent. The dataset's signalmen have a median age of 45 years, with a range of 32 to 65 . Signalmen aged $\geq 25$ years accounted for 92.6 per cent of all adult signalmen in 1911, while those aged $\geq 35$ years accounted for 65.4 per cent. ${ }^{51}$

For wages, the panel consists of men working for large companies operating in England and Wales, making it unrepresentative of their lower-paid Scottish and Irish counterparts. ${ }^{52}$ Company-specific wage data are only available for the final two years of this study. Table 2 compares the average weekly wages of the dataset's grades with the weighted average weekly wage of the three companies used in this study and of the English and Welsh companies that adopted the 1907 Scheme or the 1911 Agreement. ${ }^{53}$ The year 1912 is used to see how closely the

\footnotetext{
${ }^{48}$ Railway Companies (Staff and Wages) (P.P. 1914, LXXVII), p. 653. The figures are 25\% and $30.2 \%$ for this study's three companies.

49 TNA, Liverpool railway strike, HO 45/10655/212470. It is likely that the memo's author did not list passenger guards because his concern was the operation of goods train services.

${ }^{50}$ Earnings and Hours (P.P. 1912-13, CVIII), p. 11. The Board reported a locomotive department job ladder in which companies promoted engine cleaners to firemen and firemen to drivers.

51 Census of England and Wales, 1911 (P.P. 1913, LXXVIII), p. 1320. I have taken adults to mean those 20 years of age. The census does not differentiate between goods and passenger guards. Starting at age 25, the census reports employment figures by age every 10 years. No average age is provided.

52 Earnings and Hours (P.P. 1912-13, CVIII), p. 3. This survey is not used for comparison because it did not report company-specific wages.

${ }^{53}$ Railway Conciliation Scheme Statement of Settlements (P.P.1910, LXXX); Railway Conciliation Scheme Statement of Settlements (P.P. 1913, LVIII). The NER is included because they were one of the railway industry's largest employers.
} 
Table 2. Comparison of railwaymen's average weekly wages(in shillings), 1912

\begin{tabular}{lcccc}
\hline & Guards & (\%) & Signalmen & (\%) \\
\hline Dataset & 32.67 & 100 & 29.94 & 100 \\
GCR, GWR, LSWR & 33.13 & 8 & 29.74 & 6.8 \\
England and Wales & 32.58 & 2 & 28.26 & 1.6 \\
\hline
\end{tabular}

Notes: GCR: Great Central Railway; GWR: Great Western Railway; LSWR: London and South Western Railway. All weekly wages are nominal values in shillings. The wages for England and Wales are a weighted average of the companies that adopted the 1907 Scheme or 1911 Agreement, including the North Eastern Railway. They pertain to the week ending 7 Dec. 1911. The returns did not report guards separately and included gatemen with signalmen. The average for the three companies is also a weighted average. The columns labelled (\%) denote the number of men in that grade from the dataset as a percentage of that row's cohort. Sources: Data: railwaymen dataset (see online app. S1). 1912 wages: Railway Companies (Staff and Wages) (P.P. 1913, LVIII) Companies used for weights: Statement of Settlements (P.P. 1910, LXXX); Statement of Settlements (P.P. 1913, LVIII).

dataset's wages approximate those of the wider industry once the 1911 Agreement had taken effect. The comparisons show differences of no more than a shilling for both groups of railwaymen, except between the dataset and the English and Welsh average for signalmen. This discrepancy is probably entirely due to the railway returns including lower-paid gatemen with signalmen while the dataset does not.

The availability of employment data determined the choice of grades and years studied. The lagged objective fatal and non-fatal risk rates are reported as accidents per 100 workers employed per year. They come from the Board's annual reports on railwaymen's injuries, which listed the UK's total fatal and non-fatal injuries by grade. These returns only updated the total number employed per grade every third year. For the intervening two years this study uses the employment data provided in the returns on the hours worked by particular groups of railwaymen. These reports include the individual employment figures for each grade in this dataset, but not for other grades, apart from examiners who made up a small portion of any company's total employees. The average employment is taken for 1908 and 1909 when the hours' returns reported more than one month. The December 1902 return is the first used to calculate these three grades' employment. ${ }^{54}$

Goods guards faced the highest average annual fatal accident risk per 100 employed (0.22) from 1902 to 1912, followed by passenger guards (0.075), with signalmen (0.026) the relatively safest job of the three..$^{55}$ The top panel in figure 2 is a binned scatterplot of the natural log of the real weekly wage and the death rate lagged by one year. It shows the relationship between wages and fatal accident risk without accounting for the impact of union density, Workmen's Compensation, a man's company, his grade, or his permanent attitude towards risk. The scatterplot

\footnotetext{
${ }^{54}$ Railway Servants (Hours of Labour) (P.P. 1902-12/13). Overlapping employment figures occurred in 1901, 1907, and 1910. The ratio of the average employment from the hours data to the average employment from the accident data in these years is 1 to 0.99 for goods guards. For passenger guards and signalmen it is 1 to 1.07 and 1 to 1.03 , respectively. These discrepancies might be due to employment data taken from different months. Nonetheless, the hours' employment figures are still the best available in the years the Board did not update employment numbers.

${ }^{55}$ Railway Accidents (P.P. 1902-3, 1909-12/13); General Report (P.P. 1904-8). For the preceding decade, the Board only reported employment figures by grade in 1895 and 1898 . Average fatalities per 100 employed in these two years were higher for goods guards (0.29) and signalmen (0.03), but lower for passenger guards (0.045). The latter two grades had below-average fatalities in these two years relative to 1891-1900, suggesting the Edwardian railway industry had become safer.
} 

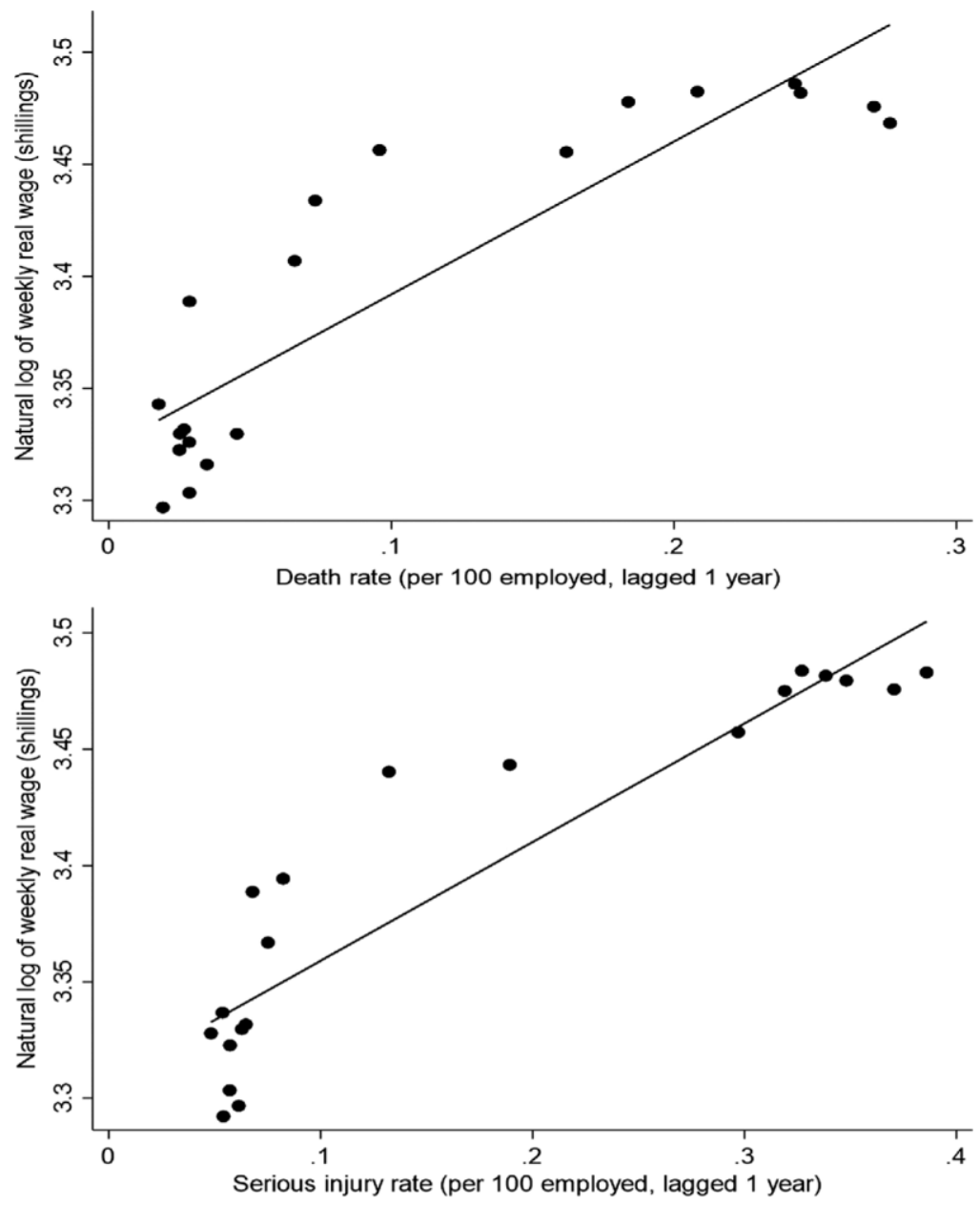

Figure 2. Natural log of weekly real wages and fatal and non-fatal accident rates

Notes: Each panel is a binned scatter plot of the natural log of real weekly wages (in shillings) on the respective accident risk rate. A regression line is included in each panel.

Source: See section II for an explanation of how the lagged death and serious injury rates were calculated for this study.

may only demonstrate the fact that goods guards earned a higher average weekly wage than passenger guards who earned more than signalmen. ${ }^{56}$ Columns 5 and 6 in table 4 answer this question.

The bottom panel in figure 2 shows this relationship for the serious non-fatal accident rate lagged by one year. The Board first set a standard definition for nonfatal injuries in 1896 when they required railway companies to report all non-fatal injuries that prevented the 'servant injured, on any one of the three working days next after the occurrence of the accident, from being employed for five hours on his ordinary work' ${ }^{57}$ This led to 50.1 per cent more non-fatal accidents being

\footnotetext{
${ }^{56}$ Earnings and Hours (P.P. 1912-13, CVIII), p. 17.

${ }^{57}$ General Report (P.P. 1897, LXXVII), p. 24.
} 
Table 3. Summary statistics

\begin{tabular}{lrrr}
\hline Variables & Mean (std. dev.) & Min. & Max. \\
\hline Natural log of weekly real wage (shillings) & $3.39(0.12)$ & 2.95 & 3.74 \\
Weekly real wage (shillings) & $29.67(3.78)$ & 19.10 & 42.09 \\
Death rate (per 100 employed, lagged 1 year) & $0.10(0.09)$ & 0.01 & 0.27 \\
Serious injury rate (per 100 employed, lagged 1 year) & $0.16(0.12)$ & 0.04 & 0.38 \\
Total employed (by grade, lagged 1 year) & $20,913(7,711)$ & 6,748 & 28,658 \\
Union density (\%) & $16.02(4.77)$ & 11.07 & 25.96 \\
Union density × death rate & $1.59(1.56)$ & 0.21 & 5.84 \\
Union density x serious injury rate & $2.67(2.35)$ & 0.61 & 10.02 \\
Workmen's Compensation 1906 (1=1908-12) & $0.45(0.49)$ & 0 & 1 \\
Workmen's Compensation 1906 × death rate & $0.04(0.07)$ & 0 & 0.24 \\
Workmen's Compensation 1906 × serious injury rate & $0.07(0.12)$ & 0 & 0.38 \\
Age (years) & $42.24(7.31)$ & 23 & 66 \\
Age squared & $1,837.79(635.49)$ & 529 & 4,356 \\
Tenure (years) & $22.38(6.96)$ & 2 & 47 \\
Tenure squared & $549.55(333.36)$ & 4 & 2,209 \\
Observations & 9,218 &
\end{tabular}

Notes: Feinstein's (National income) CPI deflates railwaymen's real weekly wages. The values for the weekly real wage (shillings) are obtained by converting the natural log figures from the preceding row into shillings. The standard deviation in the second row is calculated as $3.78 e^{3.39+0.12} e^{3.39}-$

Sources: Data: railwaymen dataset (see online app. S1). CITY: Mitchell, British historical statistics, pp. 27-9.

reported in 1896 than the previous year. ${ }^{58}$ The Board redefined what constituted a non-fatal injury at the end of 1906, now requiring railway companies to report any non-fatal accidents that caused 'the person injured to be absent from his ordinary work for a whole day at any time' ${ }^{59}$ In the following year, reported nonfatal accidents increased by 33 per cent. This article's serious non-fatal accident rate, sirate, partially mitigates this definitional change by only including injuries in which a railwayman's body part was broken or severed. From 1906 to 1907, the total number of such injuries increased by 13.7 per cent. Table 3 lists the summary statistics of the variables used in the regressions along with other variables of interest.

\section{III}

This article estimates six regressions by adding different covariates, each regression saying something different about the relationship between wages and accident rates. The full regression to be estimated is a log-linear fixed effects model. The individual-level fixed effects make it possible to control for each railwayman's time-constant characteristics that are in turn correlated with the regressions' risk variables. ${ }^{60}$ These include a railwayman's innate cognitive and physical ability and his time-constant preference for risk. The model estimated is based on Thaler and Rosen's hedonic-wage model, which showed that in equilibrium the compensating

\footnotetext{
${ }^{58}$ Ibid., p. 41.

${ }^{59}$ General Report (P.P. 1908, XCIV), p. 5.

60 The use of individual-level data is one important way in which this study differs from Kim and Fishback's study of American railroads which used job categories as the unit of observation; Kim and Fishback, 'American railroading', p. 806.
} 
differential is equal to the partial derivative of the worker's compensation in regard to accident risk. ${ }^{61}$ The full model is:

$$
\begin{aligned}
& \text { Inrwage }_{\text {ig } j t}=\text { drate }_{g t-1} \beta_{1}+\text { sirate }_{g t-1} \beta_{2}+\text { udenset } \times \text { drate } \text { dt }-1_{1} \beta_{3}+\text { udenset } \\
& \times \text { sirate }_{g t-1} \beta_{4}+W C 06 \times \text { drate }_{g t-1} \beta_{5}+W C 06 \times \text { sirate }_{g t-1} \beta_{6} \\
& + \text { agesq }_{\text {ig jt }} \beta_{7}+\text { tenuresq } q_{\text {ig } j t} \beta_{8}+\text { GRADE } \beta_{9}+\text { CITY }_{10} \\
& +Y E A R \beta_{11}+a_{i}+\varepsilon_{i g} j
\end{aligned}
$$

The dependent variable is the natural log of real weekly wages in shillings ${ }^{62}$ for railwayman $i$, in grade $g$, stationed in a city or town with population $j$, in year $t(t 1, \ldots, T)$. The average of the weekly wage is used for those years in which a railwayman's nominal weekly wage changed. The dependent variable underestimates each railwayman's weekly remuneration because it is nearly impossible to value the non-wage benefits received by railwaymen, such as uniforms, company-provided housing, or the prospect of promotion.

The variables drate and sirate are the respective fatal and serious non-fatal accident rates for a given grade per 100 employed. They are lagged by one year which makes 1902 the first year in the estimation. The lags account for the time it would take railwaymen to update their perceptions of the risk they faced, petition their superiors for a change in wages, followed by railway management or negotiations under the conciliation schemes changing the company's ILM to compensate railwaymen adequately. Limits to workers' mobility also 'reinforce a lagged influence' ${ }^{63}$ and the dataset's railwaymen worked in grades where they developed grade- and company-specific skills that limited their movement to another grade, railway company, or industry. ${ }^{64}$ Under these circumstances, an increase in workplace danger would not immediately lead to a sizeable number of employees quitting. The corollary is that companies had no incentive to lose men with company-specific skills ${ }^{65}$ by not compensating them for the accident risk they faced.

It is unlikely that these objective risk rates overestimate railwaymen's subjective assessment of their workplace risk. One contemporary argued that 'workmen as a class ... do not practically discount the wages offered in different employments by making proper allowance for the inevitable trade risk of sickness or accident'. ${ }^{66}$ This conclusion is unfair. The ASRS acknowledged that goods guards earned more than passenger guards because the former performed shunting duties which increased their risk of injury. ${ }^{67}$ Family members in the railway industry, fellow employees, and personal experience would also have served as sources of information about

\footnotetext{
61 Thaler and Rosen, 'Value of saving a life'.

${ }^{62}$ Feinstein, National income, p. T132. Feinstein's consumer price index (CPI) is used throughout to deflate nominal values.

${ }^{63}$ Kniesner et al., 'Evidence from panel data', p. 81.

64 Railway Agreements (P.P. 1911, XXIX), Q.15,979. Frank Ree, general manager of the LNWR, told a departmental committee, 'All that [a signalman] has done with the railway would be thrown away [should he leave employment there] ... Nobody wants a signalman except a railway'.

65 Ibid., Q.15,986; Williamson et al., 'Understanding', pp. 258-9.

${ }^{66}$ Flux, 'Compensation', p. 298.

${ }^{67}$ ASRS, Census of wages, p. 42.
} 
the dangers of railway work. ${ }^{68}$ The ASRS's periodical Railway Review reported the Board's accident numbers and printed articles on the deaths of railwaymen with titles such as 'Shocking death of a guard', which described the dead guard's body as 'frightfully mutilated', while 'A signalman cut to pieces' tells of a signalman whose 'brains were dashed out'. ${ }^{69}$ Modern studies have found that people tend to overestimate the potential of incurring risks that receive a large amount of media coverage such as aeroplane crashes or getting struck by lightning. ${ }^{70}$ If the same held for Edwardian workers, then lurid headlines like these were fully capable of preventing railwaymen from underestimating the danger of their jobs. ${ }^{71}$

The union density variable, udense, is ASRS membership as a percentage of non-salaried railwaymen. UPSS membership is not included in the calculation of signalmen's union density because this union played a marginal role in industrial relations during these years. From 1900 to 1912, the UPSS averaged a mere 2.8 per cent of union membership across the four main railway unions while the ASRS had an annual average of 74.1 per cent. UPSS representatives did not sign the 1907 Scheme and they had few members on the 1907 Scheme boards, making up 1.9 per cent of railwaymen elected in the UK and 0.3 per cent in England and Wales. In contrast, ASRS members made up nearly 81 per cent of railwaymen on UK boards and 83.6 per cent for England and Wales. ${ }^{72}$ The ASRS, then, was the pre-eminent railway union. The actions of their men and officials determined whether growing union density led to changes that affected railwaymen's compensating differentials.

The union density variable avoids the pitfall of not accounting for the various within-year changes that took place in this period, which would be a problem if the accident rates were interacted with a specific year or group of years. This interaction differs from papers that interacted workers' union status with risk rates because both conciliation schemes covered all of the workers in the dataset. The sign on the interaction variables and the size of the coefficients depends on the importance that railwaymen and their union representatives placed on compensating differentials. Table 4 only reports the interactions because union density is the same for every railwayman in a given year, which makes it perfectly collinear with the year dummies. The year 1912 is the final one in this study because the formation of the NUR in 1913 brought about an institutional arrangement markedly different from the oft-divided relations of the railway unions in the preceding years, while the government took over railway management in 1914 .

The Workmen's Compensation Act interactions do not have the same specificity as the union density variable. In 1899, railway companies began making payments to injured workers and the dependents of deceased workers under the Workmen's

\footnotetext{
${ }^{68}$ For some gruesome personal stories by former railwaymen, see Kenney, Men and rails, pp. 88-9; Reynolds, Engine-driving life, p. 26.

69 'Shocking death of a guard', Railway Review, 15 Jan. 1897, p. 1; 'A signalman cut to pieces', Railway Review, 4 June 1897, p. 1.

${ }_{70}^{70}$ Viscusi, Smoking, p. 25.

71 This should also counter any argument that this article's UK objective risk rates overstate risk due to Scottish railway companies having higher fatal and non-fatal accidents per train mile run than the other UK companies.

${ }^{72}$ R.C. on the Railway Conciliation Scheme of 1907. Minutes of Evidence (P.P. 1912/13, XLV), Q.1,979; p. 728. In this first election, 15 of the 17 UPSS members elected in the UK were elected to boards on Scottish railway companies, with none in Ireland. The ASLEF and GRWU members also comprised a minor percentage of seats. ASLEF members accounted for 5\% of UK seats and $6.9 \%$ of seats in England and Wales despite 1907 ASLEF membership comprising $27.7 \%$ of UK drivers, firemen, and cleaners. GRWU members filled $1.4 \%$ of UK seats and $2.1 \%$ of English and Welsh seats.
} 
Table 4. Regression results

\begin{tabular}{|c|c|c|c|c|c|c|}
\hline & \multicolumn{6}{|c|}{ Coefficient (clustered std. error) } \\
\hline & (1) & (2) & (3) & (4) & (5) & (6) \\
\hline Death rate & $0.427^{* * *}(0.030)$ & $0.369^{* * *}(0.037)$ & $-0.131(0.096)$ & $-0.105(0.095)$ & $-0.147^{*}(0.078)$ & $-0.162^{* *}(0.074)$ \\
\hline Serious injury rate & $0.168^{* * *}(0.024)$ & $0.226^{* * *}(0.028)$ & $0.736^{* * *}(0.069)$ & $0.687^{* * *}(0.069)$ & $0.290 * * *(0.044)$ & $0.287^{* * *}(0.042)$ \\
\hline $\begin{array}{l}\text { Union density } \times \text { death rate } \\
\text { injury rate }\end{array}$ & $3.109^{* * *}(0.071)$ & & $\begin{array}{r}0.044^{* * *}(0.007) \\
-0.043^{* * *}(0.004)\end{array}$ & $\begin{array}{l}0.043^{* * *}(0.00006) \\
-0.042^{* * *}(0.004)\end{array}$ & $\begin{array}{r}0.022^{* * *}(0.006) \\
-0.026^{* * *}(0.004)\end{array}$ & $\begin{array}{r}0.023^{* * *}(0.005) \\
-0.026^{* * *}(0.003)\end{array}$ \\
\hline $\begin{array}{l}\text { Workmen's Compensation } \\
1906 \times \text { death rate }\end{array}$ & & $0.206^{* * *}(0.051)$ & $-0.093(0.066)$ & $-0.121^{*}(0.065)$ & $0.012(0.063)$ & $-0.006(0.061)$ \\
\hline Workmen's Compensation & & $-0.168^{* * *}(0.036)$ & $0.129 * * *(0.048)$ & $0.145^{* * *}(0.048)$ & $-0.014(0.047)$ & $-0.0003(0.044)$ \\
\hline $\begin{array}{l}1906 \times \text { serious injury rate } \\
\text { Constant }\end{array}$ & $3.109^{* * *}(0.071)$ & $3.109 * * *(0.071)$ & $3.109^{* * *}(0.071)$ & $3.022^{* * *}(0.070)$ & $3.051^{* * *}(0.069)$ & $3.552^{* * *}(0.040)$ \\
\hline VSL in 1903 & $\pm 3,294$ & $\pm 2,84 /$ & $\pm 2,14 /$ & $\pm 2,802$ & む/4つ & $\pm / 14$ \\
\hline VSL in 1912 & $£ 3,294$ & $£ 4,436$ & $£ 7,083$ & $£ 6,868$ & $£ 3,364$ & $£ 3,310$ \\
\hline VSSI in 1903 & $£ 1,296$ & $£ 1,743$ & $£ 2,006$ & $£ 1,713$ & $£ 17$ & $-£ 6$ \\
\hline VSSI in 1912 & $£ 1,296$ & $£ 447$ & $-£ 1,938$ & $-£ 1,993$ & $-£ 3,078$ & $-£ 2,995$ \\
\hline Company dummies & No & No & No & Yes & Yes & No \\
\hline Grade dummies & No & No & No & No & Yes & Yes \\
\hline Individual fixed effects & No & No & No & No & No & Yes \\
\hline Observations & 9,218 & 9,218 & 9,218 & 9,218 & 9,218 & 9,218 \\
\hline $\mathrm{R}^{2}$ & 0.4592 & 0.4598 & 0.4635 & 0.4923 & 0.4978 & 0.3581 \\
\hline
\end{tabular}

Notes: VSL: value of a statistical life. VSSI: value of a statistical serious injury. See section IV for an explanation of the calculation of VSL and VSSI.

** $\mathrm{p}<0.01 ;{ }^{*} \mathrm{p}<0.05 ;{ }^{*} \mathrm{p}<0.1$. Clustered standard errors are in parentheses, clustering done at the individual railwayman level. The dependent variable is the natural log of weekly wages in shillings deflated by Feinstein's (National income) CPI. Cols. 1-5 are estimated using OLS, col. 6 is a fixed effects regression and $\mathrm{R}^{2}$-within is reported for this column. Variables included in all regressions but not reported are: quadratics for age and tenure, a vector of dummies controlling for the population where the railwayman worked, and a full vector of year dummies. Cols. 1-5 include age and tenure variables. The Great Central Railway is the reference company in cols. 4-5. Signalmen are the reference grade in cols. 5-6. Col. 6 does not have company dummy variables because the individual fixed effects control for each man's company since none of the men changed employers.

Source: Railwaymen dataset (see online app. S1). 
Compensation Act 1897. Expected insurance pay-outs like those guaranteed by this Act negatively affect wage premiums for accident risk ${ }^{73}$ because they are an alternative insurance to that embedded in a worker's wage. ${ }^{74}$ Previous measures of the impact of workmen's compensation legislation have calculated the expected pay-outs, which in turn depends on suitable instrumental variables, or looked at how institutional changes affected the expected pay-out. ${ }^{75}$ The first method is not feasible here because payment for fatal accidents was contingent on whether the deceased had a dependent, something these companies' staff histories did not record. Payments for non-fatal injuries depended on the length of time the man could not work, which is also unknown. For the second method, the Workmen's Compensation Act 1906 modified the initial Act, not in the amount that beneficiaries received ${ }^{76}$ but by increasing the probability that an injured railwayman or his dependents would receive compensation. Railwaymen could now claim compensation for serious or fatal injuries even if their own 'serious and wilful misconduct' caused the accident or if they were injured off their company's premises while on duty. ${ }^{77}$

The Workmen's Compensation 1906 variable exploits this institutional change in a way similar to that found in Kim and Fishback. ${ }^{78}$ It has a value of 1 for the years 1908-12, 1908 being the first full year in which the 1906 Act's changes were in effect, and 0 for the preceding six years. As for union density, this article can only report the interaction between Workmen's Compensation 1906 and the two riskrate variables. If these interactions accurately measure the increased probability of claiming compensation in the latter period, their coefficients should both have a negative sign. If they capture other changes in these years or if the new accidents covered under the regulations were rare, then the interactions may have a positive sign or a small coefficient.

The fixed effects model only includes the quadratic of age and tenure to account for diminishing returns to increases in these variables because the individual fixed effect controls for a man's age and tenure when he entered into the dataset while the year dummies account for their annual increase. The OLS estimations include the lower order terms. The GRADE vector controls for the railwayman's grade. In the absence of this control, the accident risk variables might partially control for the physical nature of a grade's duties or the differences in pay between these grades. CITY is a vector of dummies controlling for the population where the railwayman worked. ${ }^{79}$ YEAR is a full complement of year dummies that control for macroeconomic shocks, such as the unemployment rate, that would affect railwaymen's wages. They also control for institutional changes like the increase in a railwayman's wages dictated by a company's ILM or changes made

\footnotetext{
${ }^{73}$ Viscusi, 'Value of risks', pp. 1929-30; Viscusi and Moore, 'Workers' compensation'.

${ }^{74}$ Kniesner and Leeth, 'Compensating wage differentials', p. 77.

${ }^{75}$ For the former, see Moore and Viscusi, Compensation mechanisms, pp. 42, 174n. For the latter, see Fishback and Kantor, 'Workers', pp. 738-40.

${ }^{76}$ Wilson and Levy, Workmen's compensation, vol. I, pp. 109-12. Payments to men under the age of 21 increased, though no one in this dataset was that young.

${ }_{77}$ Modern Records Centre, Univ. of Warwick, reports and proceedings, MSS.127/AS/1/1/37, p. 12.

${ }^{78}$ Kim and Fishback, 'Impact', p. 241.

${ }^{79}$ London $\exists$ for those stationed in London; London_1 is for men stationed in a city with a population between London and 300,000; London_2 is for a population of 100,000-299,999; London_3 is for a population of 50,00099,999; London_4 is for a population 18,000-50,000.
} 
under the conciliation schemes, making the interaction between union density and accident rates a more precise answer to this article's central question. However, it is possible that ASRS union density and power were not necessarily distinct from one another. ${ }^{80}$

The reference category is a signalman working in a region with a population of fewer than 18,000 people in 1902. The time-constant individual fixed effect $a_{i}$ also controls for each railwayman's company in the fixed effects model because none of these men changed companies. This means it also controls for each company's time-constant attitude towards workplace safety, should such an attitude exist. The variable $u_{i g} j t$ is the error term, assumed to be uncorrelated with the independent variables.

\section{IV}

Table 4 presents the results from six different regressions with clustered standard errors in parentheses. Clustering is done at the individual railwayman level. Columns 1 to 5 are estimated using ordinary least squares (OLS), while column 6 uses the fixed effects model. The un-interacted accident rates' coefficients are large because the risk rates are calculated per 100 employees. For instance, the coefficient on death rate in column 1 implies a 42.7 per cent increase in weekly real wages in response to a one-unit increase in the lagged fatal accident risk rate. It is worth bearing in mind that the dataset's average lagged fatal accident rate is one-tenth the size of such an increase.

It is also important correctly to interpret the coefficients for death rate and serious injury rate after the inclusion of their interaction with union density. The fixed effects estimation in column 6 has all interactions and the most controls. Its death rate coefficient implies that real weekly wages would fall 16.2 per cent after the death rate increased by 1 per 100 employed. However, the death rate coefficient only measures the effect of increased fatal accident risk at a union density of 0 per cent, which table 3 shows is not historically relevant to these years. Excluding the Workmen's Compensation interactions, which are economically small, a one-unit increase in the fatal accident rate would increase a railwayman's weekly real wage by about 9.26 per cent at the lowest union density in 1903 and about 43.5 per cent at the highest union density in $1912 .{ }^{81}$ The same calculations for the serious injury rate give a return of -0.08 per cent and -38.8 per cent in 1903 and 1912, respectively.

Tofacilitate comparisons between the estimates, the implied value of a statistical life (VSL) and serious injury (VSSI) are calculated for each column at the lowest and highest level of union density. One way to think about VSL (VSSI) is that it is the total amount a railway company would have paid to compensate 100 railwaymen when their on-the-job fatal (non-fatal) accident rate increased by 1 per 100 employed. This article does not use VSL or VSSI to make normative

\footnotetext{
${ }^{80}$ Cole and Arnot, Trade unionism, pp. 46-7. By no means unbiased observers, the authors wrote that 'improvement [in the scheme for negotiating railwaymen's wages] since 1911 is due ... not to the better scheme of conciliation, but to the increased economic power of the Trade Unions'.

${ }^{81}$ The 1903 return is calculated as: $9.26=[-0.162+(0.023 \times 11.07)] \times 100$. The 1912 return is calculated as: $43.5=[-0.162+(0.023 \times 25.96)] \times 100$.
} 
judgements about policy choices. Instead, these calculations illustrate the changes in compensating differentials for fatal and serious non-fatal accident risk when their estimates include additional correlates. The estimations are made in the way common to the literature. ${ }^{82}$ VSL in 1912 is calculated as:

$$
\begin{aligned}
V S L_{1912}= & {\left.\left[\beta_{1+\left(\beta_{3} \times\right. \text { union density }}{ }_{1912}\right)+\beta_{5}\right] } \\
& \times \text { weekly real wage } \times 52 \times 100
\end{aligned}
$$

The weekly rwag $e$ is the average weekly real wage taken from table 3 and is used in all further calculations in this article to estimate the return to accident risk. It is assumed that railwaymen worked 52 weeks a year. VSL is then divided by 20 to convert its value into pounds. While the majority of the independent variables' coefficients in table 4 are statistically significant at conventional levels, the VSL and VSSI calculations include all of the respective accident-risk variables and their interactions. ${ }^{83}$

The first three columns in table 4 show how information about accident risk flowed across the railway industry by estimating the response of railwaymen's wages to changes in accident risk irrespective of a man's company or grade. Column 1's results mirror the visual relationship in figure 2. Column 2 adds the Workmen's Compensation interactions and column 3 includes the union density interactions. The highest return to fatal accident risk comes from column 3's estimation, although the results in the first three columns are open to the charge that the accident rate coefficients actually capture differences in payments between companies or occupations. ${ }^{84}$

The inclusion of company dummy variables in column 4 looks at how men within the same company recognized accident risk. This does not lead to large changes in VSL or VSSI from column 3 unlike when grade dummies are added in column 5. The 1903 VSL in column 5 is 3.84 times smaller than that in column 4 and the 1912 VSL is 2.04 times smaller. The column 5 VSSI is now economically insignificant in 1903 and negative in 1912, indicating that railwaymen received no compensation for non-fatal accident risk in these years. This means that the grade-specific accident rates in the first four columns in part reflected differences in payment between grades. The models in columns 5 and 6 are more realistic, then, because they control for each man's company and grade, which accounts for promotion limiting a railwayman's mobility between grades, while virtually eliminating it between companies.

\footnotetext{
${ }^{82}$ Kniesner and Viscusi, 'Value of a statistical life'. Hersch and Viscusi, 'Immigrant status', p. 760, refer to this equation as the 'standard equation' for calculating VSL. It also gives the same values of VSL and VSSI irrespective of how the risk variables are scaled, unlike if VSL was calculated as $V S L=\left(e^{\overline{\ln w_{\text {age }}+\beta_{1}+\beta_{3}+\beta_{5}}}-e^{\overline{\ln w_{\text {age }}}}\right)$ ₹2$\times$ 100 .

83 The accident risk variables and their interactions are highly correlated, which explains the coefficients' larger standard errors in cols. 3-6. The same is true of tab. 5's results. See Wasserstein, Schirm, and Lazar, 'Beyond " $p<0.05$ "', and Greenland, Senn, Rothman, Carlin, Pool, Goodman, and Altman, 'Statistical tests', for a discussion of the movement away from over-reliance on p-values.

${ }^{84}$ Purse, 'Work-related fatality risks', pp. 607-8. This section summarizes the findings of others that the accident rate coefficients actually capture workers' industry-specific wage differences, studies acknowledged above in $\mathrm{n} .15$. The men in this article's dataset all worked within the same industry, but tab. 4 shows that a sizeable occupational premium existed.
} 
Column 6's fixed effects model controls for each individual's time-invariant idiosyncrasies, looking at how wages responded to changes in accident risk for the individual railwayman over time. The changes in compensation for accident risk from column 5 to 6 are small, but in 6 the effect of the institutional changes in Workmen's Compensation are negative for both risk rates compared to the preceding period. However, these interactions are economically insignificant.

What does not change in any of the estimations is the sign on the interactions between the accident rates and union density. Although not reported, when these estimations exclude the non-fatal risk rate and its interactions, the coefficient on the interaction between union density and death rate has a negative sign, demonstrating how endogeneity can lead to wildly different conclusions. Alternatively, this article's results show that ASRS representatives were able to transform growing union density into power that positively impacted on the fatal accident wage premium paid to railwaymen. Column 6's estimates show that VSL grew from $£ 714$ at the lowest union density in 1903 to $£ 3,310$ at its highest in 1912. This is a range of roughly $\$ 73,263$ to $\$ 339,635$ in 2,000 US dollars calculated at purchasing power parity (PPP) exchange rates. ${ }^{85}$ Some VSL estimates from non-developed countries fall fully or partially within this range, such as Kim and Fishback's study of turn-ofthe-century US railwaymen or Liu et al.'s estimates for non-agricultural Taiwanese workers in the 1980 s. $^{86}$

These wage premiums cost the railway companies little. During the week ending 7 December 1912 the GWR employed 3,734 signalmen at a total wage bill of $£ 5,706$ in real terms. This comes to $£ 7,946$ annually for 100 signalmen, assuming the reduction in employees would not affect signalmen's weekly wages. The lagged fatal accident rate for signalmen increased by 0.011 per 100 employed from 1911 to $1912 .{ }^{87}$ Compared to a risk-free wage, the GWR would have paid $£ 36.4$ more annually to bribe these signalmen to remain working, or about 0.46 per cent of their total wage bill. The same premium is 0.48 per cent for the GCR and about 0.51 per cent for the LSWR. ${ }^{88}$ These percentages would be even lower if the employment returns had not included the lower-paid gatemen with signalmen.

From an individual railwayman's perspective, the return to this increase in fatal accident risk of 0.011 per 100 employed only reached values resembling economic significance in 1911 and 1912. Such a rise in the death rate would have increased a railwayman's annual wage by $1.57 \mathrm{~s}$., or $0.36 \mathrm{~d}$. per week, in 1903 , figures that are not economically significant. In 1912, the railwayman's annual wage would have increased by $7.28 \mathrm{~s}$., or about $1.68 \mathrm{~d}$. per week, compared to the risk-free rate. This means a railwayman would have earned 6.72d. more every four weeks in 1912

\footnotetext{
85 This article used Bank of England, 'Inflation calculator', https://www.bankofengland.co.uk/monetary-policy/ inflation/inflation-calculator (accessed on 17 March 2021), to convert VSL estimates from 1904 to 2000 GBP. It then used Organisation for Economic Co-operation and Development, 'Conversion rates: purchasing power parities', https://data.oecd.org/conversion/purchasing-power-parities-ppp.htm (accessed on 17 March 2021), PPP exchange rates, to convert to 2000 USD.

${ }^{86}$ American railways: Kim and Fishback, 'American railroading', pp. 811-12; Viscusi and Aldy, 'Value of a statistical life', p. 22. Taiwan: Liu, Hammitt, and Liu, 'Estimated hedonic wage function', p. 357; Viscusi and Aldy, 'Value of a statistical life', p. 28.

${ }^{87}$ This is close to the largest one-year increase in signalmen's death rate, which was 0.017 from 1907 to 1908 .

${ }^{88}$ Railway Companies (Staff and Wages) (P.P. 1913, LVIII), pp. 566-76. This article did not make the same calculations for goods or passenger guards because the employment returns do not list their average wages separately.
} 
when seven pounds of potatoes cost 3.5-4.5d., four pounds of bread cost 5.5-6d., and a pound of frozen mutton cost $4.5-5 \mathrm{~d} .{ }^{89}$ Using an accident-risk premium of $5 \mathrm{~d}$. more every four weeks as the minimum threshold for economic significance, a railwayman would have received this much at a union density o $\$ 21.2$ per cent. Union density only exceeded this level in 1911 when railwaymen went on strike and in 1912 when the 1911 Agreement took effect.

Unlike fatal accident risk, the return to non-fatal accident risk is negative at every historical level of union density based on column 6's results. The sign on the interaction between union density and serious injury risk is also negative in all estimations where it is included. That bearing greater non-fatal accident risk went unremunerated may in part stem from measurement error due to the Board's 1906 redefinition of what constituted an injury. Because this article somewhat minimized this problem by only including the most severe workplace injuries, it more likely suggests that a wage premium for serious injury risk was the opportunity cost of a higher wage premium for fatal accident risk.

These outcomes fit with the wider knowledge of the Edwardian railway industry. First, it is logical that railway companies would acquiesce to higher compensating differentials for fatal accident risk if it meant only a marginal increase in their total labour costs. There is also agreement that railwaymen achieved improved wages under the 1911 Agreement after failing to do so under the 1907 Scheme, ${ }^{90}$ increases that better compensated men for accepting on-the-job fatal accident risk. These wage premiums were also at their highest in 1912 after Lloyd George agreed in 1911 that the government would consider allowing railway companies to charge higher rates to cover higher labour costs. ${ }^{91}$ This is not to downplay the role played by union representatives and railwaymen who received their highest levels of compensation for fatal accident risk after they went on strike in 1911. More specific to the ASRS, the Board deemed dangerous the work of all the grades in table 1 except signalmen. ${ }^{92}$ The other five grades accounted for close to 59 per cent of ASRS membership in 1911, which makes it quite likely that the ASRS pushed for wages to better insure the at-risk grades that comprised a sizeable portion of their membership. ${ }^{93}$

The change in ASRS leadership may provide another reason why railwaymen's compensating differentials were highest in 1911 and 1912.J.E. Williams succeeded Richard Bell as general secretary of the ASRS in 1910 after the ASRS accepted Bell's 1909 resignation with unanimous approval. ${ }^{94}$ Both had worked for the GWR, Bell as a guard, Williams as a signalman. Despite working in the safer grade, Williams lost a leg in an 1877 railway accident. ${ }^{95}$ Bell was also a more cautious leader, who said that his personal motto was 'Slow, Sure, and Determined', and he never 'agitated for agitation's sake'. ${ }^{96}$ This change in leadership does

\footnotetext{
${ }^{89}$ Cost of Living (P.P. 1912-13, LXVI), p. 433.

${ }^{90}$ Bagwell, Railwaymen, p. 305; Clegg, History of British trade unions, vol. 2, p. 39; Gourvish, Railways, pp. $53-$ 4. All three authors based this conclusion on changes in railwaymen's average earnings reported in the Board's annual Wages and Hours of Labour (P.P. 1903-14/16, Annual Returns).

${ }^{91}$ Alderman, 'Railway companies', pp. 148-9.

92 General Report (P.P. 1907, LXXIV), p. 17.

${ }^{93}$ It is assumed that passenger guards again accounted for 4\% of ASRS membership in 1911.

94 Gupta, 'History', pp. 435-6.

95 Ibid., p. 445.

96 'How I got on-Richard Bell', Pearson's Weekly, 15 Feb. 1906, p. 577.
} 
not conclusively explain why railwaymen received the highest compensating differentials for fatal accident risk in 1911 and 1912, but it is not implausible that the ASRS sought higher such premiums in the years they were led by a man who had suffered a serious injury during his time working as a railwayman.

The rest of this section looks at how the relationship between union density and accident-risk premiums may have differed based on a man's company-specific human capital as measured by tenure, ${ }^{97}$ which to my knowledge is the first analysis of this kind. The firm-specific human capital model posits that once an employee is matched with a firm, both will make investments specific to the other leading to the match becoming more lucrative over time. ${ }^{98}$ In such a scenario, railway companies would have preferred acquiescing to higher pay and accident risk premiums for longer-tenured men. This in turn may have dovetailed with a desire by the ASRS to reward more senior members, although no evidence of this has been found in this study. In contrast, railwaymen with less company-specific capital would have been more inclined to quit if the accident-risk premiums they received did not compensate them adequately, these competitive pressures then increasing their compensating differentials.

To test this, the panel is divided into four cohorts based on their 1912 tenure. Table 5 lists the cohorts, with the average age of each in 1912 beside it in parentheses. Some of the tenures are quite long, due to men joining the company as a 'lad', 99 and the high degree of correlation between tenure and age means these results may in part show how union density affected compensating differentials at different age levels. The fixed effects regression is used for all groups because it controls for the most variables correlated to the accident risk variables, and values of VSL and VSSI are presented as in table 4. The results show that higher union density lowered the return to serious injury risk for all three cohorts apart from the least-tenured. At 1912 union density, this first group would have received an economically significant return at a minimum increase in non-fatal injury risk of 0.034 per 100 employed, which falls within the range of changes in the serious injury rate from 1911 to 1912 for these three grades. ${ }^{100}$

For fatal accident risk, the results show a non-linear relationship across the four cohorts. 'Wage levelling' occurs in the least-tenured cohort, which perhaps came at the cost of them receiving higher premiums for serious non-fatal accidents. The two cohorts with tenures of 20-29 and 30-39 years received the highest wage premiums for fatal accident risk from 1911 to 1912, their respective 1912 VSLs larger than the VSL for all railwaymen in column 6 of table 4. For the longest-tenured cohort, the coefficients on death rate and its interactions are not statistically significant at conventional levels, nor is the interaction between Workmen's Compensation and the serious injury rate. This is probably due to the high degree of correlation between these variables which are statistically significant in a joint test at the 1 per

\footnotetext{
${ }^{97}$ It is not possible to estimate compensating differentials with separate regressions for each grade because there is no within-year variation in the accident risk rates at the grade level.

98 Siebert and Addison, 'Internal labour markets', pp. 82-3.

${ }^{99}$ For its youngest employees, railway companies had grade classifications that denoted them as 'lads', such as Lad Porters or Lad Lampmen.

${ }^{100}$ From 1911 to 1912 , the serious injury rate fell for passenger guards and signalmen, but increased by 0.053 per 100 employed for goods guards.
} 
Table 5. Regression results for cohorts of railwaymen by company-specific tenure

\begin{tabular}{|c|c|c|c|c|}
\hline & \multicolumn{4}{|c|}{ Cohorts (average age) } \\
\hline & $12-19(40.3)$ & $2 O-9(44.2)$ & $30-9(52.8)$ & $40-7(59.5)$ \\
\hline Death rate & $1.129^{* * *}(0.305)$ & $-0.212^{* *}(0.101)$ & $-0.356^{* * *}(0.116)$ & $-0.204(0.238)$ \\
\hline Serious injury rate & $-0.482^{* *}(0.233)$ & $0.324^{* * *}(0.057)$ & $0.361^{* * *}(0.067)$ & $0.418^{* * *}(0.130)$ \\
\hline Union density $\times$ death rate & $-0.073^{* * *}(0.025)$ & $0.027^{* * *}(0.007)$ & $0.038^{* * *}(0.009)$ & $0.028(0.019)$ \\
\hline $\begin{array}{l}\text { Union density } \times \text { serious } \\
\text { injury rate }\end{array}$ & $0.038^{* *}(0.017)$ & $-0.028^{* * *}(0.005)-$ & $-0.035^{* * *}(0.006)-0.0$ & $37^{* * *}(0.012)$ \\
\hline $\begin{array}{l}\text { Workmen's Compensation } \\
1906 \times \text { death rate }\end{array}$ & $0.570^{* * *}(0.185)$ & $0.006(0.078)$ & $-0.152(0.115)$ & $-0.109(0.205)$ \\
\hline $\begin{array}{l}\text { Workmen' Compensation } \\
1906 \times \text { serious injury rate }\end{array}$ & $-0.401^{* * *}(0.144)$ & $-0.012(0.057)$ & $0.104(0.083)$ & $0.038(0.160)$ \\
\hline Constant & $3.394^{* *}(0.072)$ & $3.532^{* * *}(0.048)$ & $3.444^{* * *}(0.090)$ & $3.651^{* * *}(0.499)$ \\
\hline VSL in 1903 & $£ 2,475$ & $£ 670$ & $£ 498$ & $£ 817$ \\
\hline VSL in 1912 & $-£ 1,513$ & $£ 3,817$ & $£ 3,691$ & $£ 3,193$ \\
\hline VSSI in 1903 & $-£ 473$ & $£ 108$ & $-£ 204$ & $£ 65$ \\
\hline VSSI in 1912 & $£ 798$ & $-£ 3,200$ & $-£ 3,422$ & $-£ 3,892$ \\
\hline Observations & 649 & 5,280 & 3,014 & 275 \\
\hline $\mathrm{R}^{2}$-within & 0.6528 & 0.4276 & 0.1556 & 0.3917 \\
\hline
\end{tabular}

Notes: VSL: value of a statistical life. VSSI: value of a statistical serious injury. See section IV for an explanation of the calculation of VSL and VSSI. " * $\mathrm{p}<0.01 ;{ }^{* *} \mathrm{p}<0.05 ;{ }^{*} \mathrm{p}<0.1$. Cohorts are for company-specific tenure as of 1912 . The average age of each cohort in 1912 is reported below it in parentheses. Clustered standard errors are in parentheses beside the coefficients, clustering done at the individual railwayman level. The dependent variable is the natural log of weekly wages in shillings deflated by Feinstein's (National income) CPI. Variables included in all regressions but not reported are: quadratics for age and tenure, grade dummies, a vector of dummies controlling for the population where the railwayman worked, and a full vector of year dummies. The reference category is a signalman working at a station in a place with a population of less than 18,000 in 1902. Due to lack of variation, the grade dummies are perfectly collinear with the individual fixed effects in the first and fourth cohorts, as is the passenger guard dummy variable in the third cohort. Three of the five population dummies are perfectly collinear with the individual fixed effects in the fourth cohort. London_4 is the reference variable for this cohort.

Source: Railwaymen dataset (see online app. S1).

cent level. ${ }^{101}$ Calculation of this cohort's 1912 VSL finds that it is smaller than that of the middle two cohorts, suggesting that the relationship between employer and employee diminished in value after an extended amount of time with one company. Table 5's results would probably apply to other promoted railwaymen, such as firemen and engine drivers, whose work benefited from the accumulation of gradeand company-specific human capital. ${ }^{102}$ Entry-level grades like porters and shunters would have had lower tenures, but sold their labour in the context of a more competitive market which should have led to higher compensating differentials. In terms of company-specific human capital, though, companies would have valued these entry-level grades less.

\section{$\mathrm{V}$}

This article has found a number of interesting results pertaining to how union density impacts compensating differentials for workplace accident risk and how this relationship functioned within the historical context of the Edwardian English and Welsh railway industry. In regard to estimation, this article's regressions controlled for variables that previous studies often omitted, such as the non-fatal risk rate

\footnotetext{
101 The coefficients for death rate and its two interactions are statistically significant in a joint test at the $10 \%$ level.

102 TNA, No. 2, RAIL 264/10, p. 90.
} 
and institutional changes in Workmen's Compensation. Most importantly, its novel application of a balanced panel of railwaymen to this question eliminated another source of endogeneity by having fixed effects control for time-invariant individual characteristics correlated with the accident-risk variables. The panel was then used to study how union density affected compensating differentials, looking at changes in this relationship over time at the individual level.

The results of the regressions show that the ASRS mobilized growing union density into power that positively affected railwaymen's compensating differentials for fatal accident risk, but not for non-fatal accident risk, the returns to which were negative in the fullest model estimated. A closer look at the return to fatal accident risk showed that it was highest in the final two years of this study. This corroborates earlier, less rigorous conclusions that railwaymen did not achieve improved wages until after the railway strike of August 1911 and the adoption of the 1911 Agreement. These are the years in this study during which union density was at its highest and when railway companies had received a promise that they could increase the rates they charged to cover higher wage costs.

Finally, the article assessed how the level of company-specific human capital may have impacted on the relationship between union density and compensating differentials. The results showed a non-linear relationship for both risk-rate variables. Higher union density increased the return to non-fatal accidents for the least-tenured cohort, but not the others. Conversely, union density had a levelling effect on the least-tenured cohort's return to fatal accident risk. This return was positive for the other three cohorts, although the longest-tenured cohort received the lowest return of the three by 1912, indicating that the value of company-specific tenure diminished over time. It is plausible that these findings would hold for other non-entry-level grades in the railway industry.

DOI: $10.1111 / \mathrm{ehr} .13066$

\section{Footnote references}

Alderman, G., 'The railway companies and the growth of trade unionism in the late nineteenth and early twentieth centuries', Historical Journal, 14 (1971), pp. 129-52.

Anderson, P., 'Tall and lithe": the wage-height premium in the Victorian and Edwardian British railway industry', Explorations in Economic History, 67 (2018), pp. 152-62.

ASRS (Amalgamated Society of Railway Servants), Report giving statement of the results of the census of wages, hours oflabour, \&c., of men (in those grades referred to in the demands of the ASRS) employed on the railways of the United Kingdom (1908).

Bagwell, P. S., The Railwaymen: the history of the National Union of Railwaymen (1963).

Clegg, H. A., A history of British trade unions since 1889, II: 1911-1933 (Oxford, 1985).

Clegg, H. A., Fox, A., and Thompson, A. F., A history of British trade unions since 1889, I: 1889-1910 (Oxford, 1964).

Cole, G. D. H. and Arnot, R. P., Trade unionism on the railways, its history and problems (1917).

Crouch, C., Trade unions: the logic of collective action (1982).

Dillingham, A. E., 'The influence of risk variables definition on value-of-life estimates', Economic Inquiry, 23 (1985), pp. 277-94.

Dorman, P. and Hagstrom, P., 'Wage compensation for dangerous work revisited', Industrial and Labor Relations Review, 52 (1998), pp. 116-35.

Dorsey, S. and Walzer, N., 'Workers' compensation, job hazards, and wages', Industrial and Labor Relations Review, 36 (1983), pp. 642-54.

Fairris, D., 'Compensating wage differentials in the union and nonunion sectors', Industrial Relations, 28 (1989), pp. 356-72.

Feinstein, C. H., National income, expenditure and output of the United Kingdom, 1855-1965 (Cambridge, 1972). 
Fishback, P. V. and Kantor, S. E., "'Square deal” or raw deal? Market compensation for workplace disamenities, 1884-1903', Journal of Economic History, 52 (1992), pp. 826-48.

Fishback, P. V. and Kantor, S. E., 'Did workers pay for the passage of workers' compensation laws?', Quarterly Journal of Economics, 110 (1995), pp. 713-42.

Flux, A. W., 'Compensation for industrial accidents', Transactions of the Manchester Statistical Society (1897-8), pp. 267-306.

Gourvish, T. R., Railways and the British economy 1830-1914 (1980).

Greenland, S., Senn, S. J., Rothman, K. J., Carlin, J. B., Poole, C., Goodman, S. N., and Altman, D. G., 'Statistical tests, $P$ values, confidence intervals, and power: a guide to misinterpretations', European Journal of Epidemiology, 31 (2016), pp. 337-50.

Gupta, P.S., 'History of the Amalgamated Society of Railway Servants, 1871-1913' (unpub. D.Phil. thesis, Univ. of Oxford, 1960).

Gupta, P. S., 'Railway trade unionism in Britain, c. 1880-1900', Economic History Review, 2nd ser., XIX (1966), pp. 124-53.

Health and Safety Executive, RIDFATAL: RIDDOR reported fatal injuries tab 1 (2107/18), https://www.hse.gov.uk/ statistics/tables/ridfatal.xlsx (accessed on 11 Dec. 2019)

Hersch, J. and Viscusi, W. K., 'Immigrant status and value of a statistical life', Journal of Human Resources, 45 (2010), pp. 749-71.

Howell, D., Respectable radicals: studies in the politics of railway trade unionism (New York, 1999).

Howlett, P., 'Evidence of the existence of an internal labour market in the Great Eastern Railway company, 18751905', Business History, 42 (2000), pp. 21-40.

Howlett, P., 'The internal labour dynamics of the Great Eastern Railway Company, 1870-1913', Economic History Review, LVII (2004), pp. 396-422.

Kenney, R., Men and rails (1913).

Kim, S.-W. and Fishback, P. V., 'Institutional change, compensating differentials, and accident risk in American railroading, 1892-1945', Journal of Economic History, 53 (1993), pp. 796-823.

Kim, S.-W. and Fishback, P. V., 'The impact of institutional change on compensating wage differentials for accident risk: South Korea, 1984-1990', Journal of Risk and Uncertainty, 18 (1999), pp. 231-48.

Kniesner, T. J. and Leeth, J. D., 'Compensating wage differentials for fatal injury risk in Australia, Japan, and the United States', Journal of Risk and Uncertainty, 4 (1991), pp. 75-90.

Kniesner, T.J. and Viscusi, W.K., 'The value of a statistical life', in Oxford research encyclopedia of economics and finance (Oxford, 2019), https://law.vanderbilt.edu/phd/faculty/w-kip-viscusi/publications.php (accessed on 10 Dec. 2020).

Kniesner, T.J., Viscusi, W.K., Woock, C., and Ziliak, J. P., 'The value of a statistical life: evidence from panel data', Review of Economics and Statistics, 94 (2012), pp. 74-87.

Lavetti, K., 'The estimation of compensation wage differentials: lessons from the Deadliest catch', Journal of Business and Economic Statistics, 38 (2020), pp. 165-82.

Leigh, J. P., 'Compensating wages, value of a statistical life, and inter-industry differentials', Journal of Environmental Economics and Management, 28 (1995), pp. 83-97.

Lévesque, C. and Murray, G., 'Understanding union power: resources and capabilities for renewing union capacity', Transfer, 16 (2010), pp. 333-50.

Liu, J.-T., Hammitt, J. K., and Liu, J.-L., 'Estimated hedonic wage function and value of life in a developing country', Economic Letters, 57 (1997), pp. 353-8.

Lukes, S., Power: a radical view (Basingstoke, 2005).

Mitchell, B. R., British historical statistics (Cambridge, 2011 reprint).

Moore, M. J. and Viscusi, W. K., Compensation mechanisms for job risks: wages, workers' compensation and product liability (Princeton, NJ, 1990).

Purse, K., 'Work-related fatality risks and neoclassical compensating wage differentials', Cambridge Journal of Economics, 28 (2004), pp. 597-617.

Reynolds, M., Engine-driving life: or, stirring adventures and incidents in the lives oflocomotive engine-drivers (1881).

Savage, M., 'Discipline, surveillance and the "career": employment on the Great Western Railway 18331914', in A. McKinlay and K. Starkey, eds., Foucault, management and organization theory (1998), pp. 65-92.

Siebert, W.S. and Addison, J. T., 'Internal labour markets: causes and consequences', Oxford Review of Economic Policy, 7 (1991), 76-92.

Smith, A., The wealth of nations, books I-III (1999 edn.).

Thaler, R. and Rosen, S., 'The value of saving a life: evidence from the labor market', in N. E. Terleckyj, ed., Household production and consumption (New York, 1975),pp. 265-98.

Viscusi, W. K., Smoking-making the risky decision (Oxford,1992).

Viscusi, W. K., 'The value of risks to life and health', Journal of Economic Literature, 31 (1993), pp. $1912-46$.

Viscusi, W. K. and Aldy, J. E., 'The value of a statistical life: a critical review of market estimates throughout the world', Journal of Risk and Uncertainty, 27 (2003), pp. 5-76. 
Viscusi, W. K. and Moore, M. J., 'Workers' compensation: wage effects, benefit inadequacies, and the value of health losses', Review of Economics and Statistics, 69 (1987), pp. 249-61.

Wardley, P., 'The emergence of big business: the largest corporate employers of labour in the United Kingdom, Germany and the United States c. 1907', Business History, 41 (1999), pp. 88-116.

Wasserstein, R. L., Schirm, A. L., and Lazar, N. A., 'Moving to a world beyond " $p<0.05$ ", American Statistician, 73 (2019), pp. 1-19.

Webb, S. and Webb, B., The history of trade unionism, 1666-1920 (1919).

Williamson, O. E., Wachter, M. L., and Harris, J. E., 'Understanding the employment relation: the analysis of idiosyncratic exchange', Bell Journal of Economics, 6 (1975), pp. 250-78.

Wilson, A. and Levy, H., Workmen's compensation, I: Social and political development (1939).

\section{Official publications}

Census of England and Wales, 1911. Vol. X. Occupations and Industries (P.P. 1913, LXXVIII).

Cost of Living of the Working Classes. Report of an Enquiry by the Board of Trade into Working Class Rents and Retail Prices, together with the Rates of Wages in Certain Occupations in Industrial Towns in the United Kingdom in 1912 (P.P. 1912/13, LXVI).

Earnings and Hours Enquiry. Report of an Enquiry by the Board of Trade into the Earnings and Hours of Labour of Workpeople of the United Kingdom. VII.-Railway service in 1907 (P.P. 1912-13, CVIII).

Friendly Societies, Workmen's Compensation Schemes, Industrial and Provident Societies, and Trade Unions (P.P.190314, Annual Returns).

General Report to Board of Trade on Accidents on Railways (P.P. 1897, 1904-8).

Railway Accidents. Returns of Accidents and Casualties (P.P. 1902-3, 1909-12/13).

Railway Agreements and Amalgamations (P.P. 1911, XXIX).

Railway Companies (Staff and Wages), 1911-12 (P.P. 1913, LVIII).

Railway Companies (Staff and Wages) (P.P. 1914, LXXVII).

Railway Conciliation Scheme. Statement of Settlements (P.P. 1910, LXXX).

Railway Conciliation Scheme. Statement of Settlements (P.P. 1913, LVIII).

Railway Servants (Hours of Labour) (P.P. 1902-12/13).

Royal Commission on Accidents to Railway Servants (P.P. 1900, XXVII).

Royal Commission on the Railway Conciliation Scheme of 1907. Minutes of Evidence (P.P. 1912/13, XLV).

Royal Commission on the Railway Conciliation Scheme of 1907. Report of the Royal Commission (P.P. 1911, XXIX).

Statistics of Compensation and of Proceedings under the Workmen's Compensation Act, 1906, and the Employers' Liability Act, 1880 (P.P. 1909-14-16).

Strikes and Lock-outs (P.P. 1912-13, XLVII).

Wages and Hours of Labour. Board of Trade (P.P. 1903-14/16, Annual Returns).

\section{Supporting information}

Additional supporting information may be found online in the Supporting Information section at the end of the article.

\section{S1. Railwaymen dataset}

S2. STATA commands

Data and replication files for this article are deposited with the Inter-university Consortium for Political and Social Research: https://doi.org/10.3886/E129961V1. 